\title{
Synthesis and Electrochemical Performance of Aluminum Based Composites
}

\author{
Xue-feng Lei and Jun-xian Ma* \\ Department of Chemistry \& Biology, University of Electronic Science and Technology of China, \\ Zhongshan Institute, Zhongshan 528402, P. R. China
}

\begin{abstract}
O alumínio é um material anódico muito atrativo para baterias de íon lítio quando são melhorados o enfraquecimento rápido de capacidade e os ciclos de desempenho. Para solucionar esses problemas, compósitos de alumínio/carbono foram sintetizados utilizando álcool polivinílico (PVA) como fonte de carbono. As amostras foram caracterizadas por análise termogravimétrica e calorimetria diferencial de varredura (DSC-TGA), análise do tamanho de partículas, difração de raios-X (XRD), microscopia eletrônica de varredura (SEM) e ciclos galvanostáticos. Embora a capacidade irreversível inicial aumente devido à presença do carbono, o compósito exibe um aumento no ciclo de desempenho. O compósito com alto teor de carbono (compósito B) possui retenção de capacidade de 58\% após 15 ciclos que é muito maior que a do alumínio puro (21\%). Os resultados indicam que o carbono pulverizado é um método possível para melhorar o desempenho eletroquímico do alumínio metálico.
\end{abstract}

Aluminum is a very attractive anode material for lithium ion batteries if the fast capacity fading and cycle performance are improved. Al/carbon composites were synthesized using polyvinyl alcohol (PVA) as carbon source to solve these problems. The samples were characterized by thermogravimetric analysis and differential scanning calorimetry (DSC-TGA), particle size analysis, X-ray diffraction (XRD), scanning electron microscope (SEM) and galvanostatic cycling. Although the initial irreversible capacities increase due to the presence of carbon, the composites exhibit improved cycle performance. The composite with high carbon content (composite B) possesses capacity retention of $58 \%$ after 15 cycles, which is much higher than that of pure aluminum $(21 \%)$. Results indicate that carbon coating is a feasible method to improve the electrochemical performance of metal aluminum.

Keywords: lithium ion battery, anode, aluminum based composites, synthesis, electrochemical performance

\section{Introduction}

Aluminum has been proposed as anode material for lithium ion batteries because of its high capacity, flat potential profile and low cost. ${ }^{1}$ Nevertheless, the practical use of this metal is not yet feasible. The key problem is that aluminum particles suffer cracking and crumbling during cycling, which results in fast capacity fading and poor cycle life. ${ }^{2}$ To overcome these problems, Al-based intermetallic materials such as $\mathrm{Al}_{2} \mathrm{Cu}, \mathrm{Al}_{6} \mathrm{Mn}, \mathrm{AlSb}$ and $\mathrm{Fe}_{2} \mathrm{Al}_{5}$ have been investigated. ${ }^{3,4}$ However, all these materials give small reversible capacities in the first cycle and show fast capacity fading. Particulatereinforced composites or mixtures, for instance, $\mathrm{Al}-\mathrm{SiC}$ and $\mathrm{Al}-\mathrm{Al}_{3} \mathrm{Ni}$, have also been exploited. ${ }^{5,6} \mathrm{Among}$ these composites or mixtures, aluminum acts as an active component storing

*e-mail: mjxld@yahoo.com.cn lithium, while the other component is unalloyable with lithium and serves only for the improvement of the mechanical stability. Compared with pure aluminum, these composites possess better mechanical stability and cycle performance.

In this report, $\mathrm{Al} /$ carbon composites were synthesized to improve the cycle performance of aluminum, in which both $\mathrm{Al}$ and carbon are active to store lithium. The electrochemical properties of these composites were investigated and compared with those of pure aluminum. Furthermore, the effects of carbon layer on the composite electrodes were discussed.

\section{Experimental}

\section{Preparation of the composites}

The aluminum powder was used as received. All other chemicals were AR grade. The preparation of $\mathrm{Al} /$ carbon 
composites is as follows. First, PVA124 was dissolved in hot distilled water with continuous stirring. Then, $\mathrm{LiOH} \cdot \mathrm{H}_{2} \mathrm{O}$ in a weight ratio of 1:1 to PVA was added step by step. The obtained opal gel was dried in oven at $100^{\circ} \mathrm{C}$ for 3 days to form dried black product. This product was grinded, immersed in distilled water and filtered for several times until the $\mathrm{pH}$ of the filtrate reached 7 . Then, it was heat treated at $400{ }^{\circ} \mathrm{C}$ for $3 \mathrm{~h}$ under argon atmosphere to obtain a precursor. The precursor was mixed and grinded with $\mathrm{Al}$ powder in the weight ratio of 3:10 and 5:10 respectively. After grinding, the mixtures were heat treated at $650{ }^{\circ} \mathrm{C}$ for $3 \mathrm{~h}$ in argon atmosphere, thus the composites with different carbon content were obtained. The composite with low carbon content is labeled as composite $\mathrm{A}$, the other with high carbon content is labeled as composite B.

\section{Apparatus}

The thermogravimetric analysis (TGA) and differential scanning calorimetry (DSC) measurements were conducted by SDT Q600 thermal analyzer, the samples were heated to $800^{\circ} \mathrm{C}$ at a rate of $15^{\circ} \mathrm{C} \mathrm{min}^{-1}$ under nitrogen atmosphere. The particle size was measured by Malvern Mastersizer 2000. The X-ray power diffraction (XRD) measurements were carried out with a Shimadzu XRD6000 diffractometer with $\mathrm{Cu}-\mathrm{K} \alpha_{1}$ radiation $(\lambda=1.54056 \AA)$. The scanning electron microscope (SEM) images were observed by means of Hitachi SEM X650 performed at $25 \mathrm{kV}$.

\section{Electrochemical characterization}

Coin cells were used for electrochemical tests. Slurries prepared were consisted of $60 \mathrm{wt} . \%$ active materials, $25 \mathrm{wt} . \%$ acetylene black and $15 \mathrm{wt} . \%$ polytetrafluoroethylene (PTFE) binder. Lithium metal was used as a counter electrode, and $1 \mathrm{~mol} \mathrm{~L}^{-1} \mathrm{LiPF}_{6}$ solution in a 1:1 (v/v) mixture of ethylene carbonate (EC) and dimethyl carbonate (DMC) was used as electrolyte. The cells were assembled in an argon-filled glove box (Mikrouna-China Super 1220/750). Cells were charged and discharged galvanostatically with current density $100 \mathrm{~mA} \mathrm{~g}^{-1}$ in the range of 0.001 to $1.5 \mathrm{~V}$ at $25^{\circ} \mathrm{C}$. The electrochemical properties were examined using Neware cell test system.

\section{Results and Discussion}

\section{Synthesis of Al/carbon composites}

It is well known that for low temperature pyrolytic carbons, higher $\mathrm{H} / \mathrm{C}$ ratios result in larger irreversible capacity loss and voltage hysteresis in the first cycle. ${ }^{7,8}$
In order to reduce the $\mathrm{H} / \mathrm{C}$ ratio, PVA124 was pretreated using lithium hydroxide as dehydrogenation reagent before pyrolysis. It was reported that the complete alcoholysis PVA could be partial oxidized by abundant alkali when the temperature reachs $80^{\circ} \mathrm{C}$. In the PVA chains, part of hydroxy is dehydrogenated, forming unsaturated $\mathrm{C}=\mathrm{O}$ bonds. We hope the pretreatment of PVA could play a role in reducing irreversible capacity of carbon material in the first cycle.

The DSC-TGA curves of original PVA and the pretreated PVA were measured to explore the influence of lithium hydroxide on the decomposition behavior of PVA, simultaneously, to ascertain the seemly reaction temperature. Figure 1a gives the DSC-TGA curves of original PVA. In the TGA curve, the initial weight loss before $200{ }^{\circ} \mathrm{C}$ is related to the loss of adsorbed water. The followed weight loss detected between 230 and $400{ }^{\circ} \mathrm{C}$ is attributed to a rapid chain-stripping elimination of water to form polyene, and the third weight loss appeared after $400{ }^{\circ} \mathrm{C}$ is due to the further degradation of the main chain,,${ }^{910}$ which completed at $600{ }^{\circ} \mathrm{C}$. In the DSC curve, a weak endothermic peak appeared at $226^{\circ} \mathrm{C}$ is assigned to the melting peak of PVA. The followed endothermic peak at $298{ }^{\circ} \mathrm{C}$ and a big exothermic peak at $521{ }^{\circ} \mathrm{C}$ are corresponding to the elimination of water and the further degradation in the TGA curve respectively. Compared with original PVA, the DSC-TGA curves of the pretreated PVA change markedly. First of all, the stage of thermal elimination of water finishes at around $350{ }^{\circ} \mathrm{C}$, this temperature is lower than that of original PVA, and the corresponding endothermic peak also removes to lower temperature $\left(250{ }^{\circ} \mathrm{C}\right)$, which can be explained that the dehydrogenation of alkali weakens the function of hydrogen bonding of the PVA chains, thus the thermal elimination of water finishes at lower temperature. Another noticeable difference is that the further decomposition of the main chain of pretreated PVA is accomplished via two steps, the polymer is completely carbonized until $650^{\circ} \mathrm{C}$. Thereby, the final heat treatment temperature is ascertained at $650{ }^{\circ} \mathrm{C}$ in the synthesis process.

\section{Characterization of Al/carbon composites}

The measurement of particle size and particle size distribution shows that the average particle size of aluminum matrix is $36.682 \mu \mathrm{m}$ (the figure was omitted). The XRD patterns of pure aluminum and composite $\mathrm{B}$ are shown in Figure 2. The four strong diffraction peaks at $2 \theta$ values of $38.45,44.71,65.09$ and $78.23^{\circ}$ are characteristic of metallic aluminum [JCPDS No. 89-4037]. In addition, a weak and broad peak can be observed in Figure $1 \mathrm{~b}$ at around $23^{\circ}$, indicating the existence of amorphous carbon. 

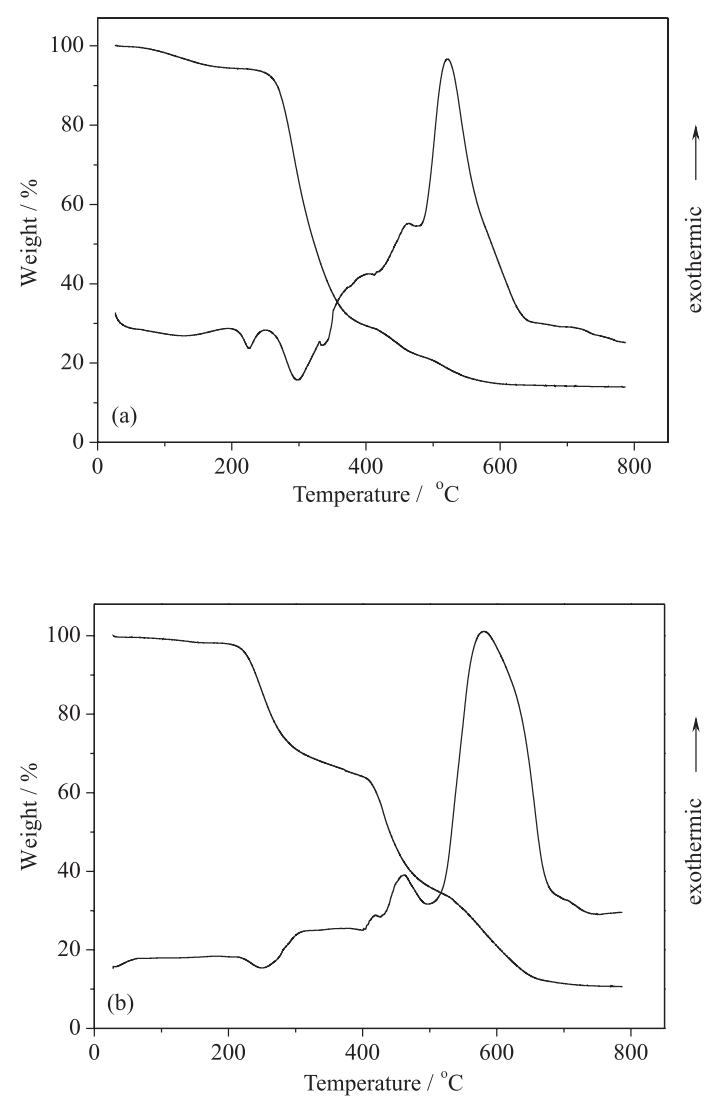

Figure 1. DSC-TGA curves of original PVA and the pretreated PVA: (a) original PVA and (b) the pretreated PVA.

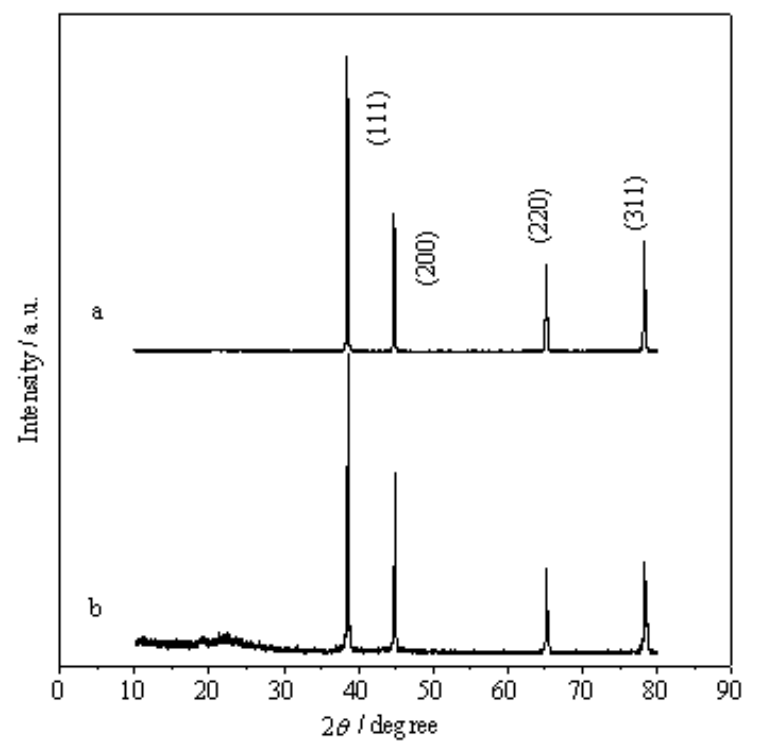

Figure 2. XRD patterns of pure aluminum and $\mathrm{Al} /$ carbon composites: (a) pure aluminum and (b) composite B.

Figure 3a shows the SEM image of pure aluminum powder. It appears that the aluminum particles are almost spherical, whose surface is smooth and clear without any impurity. In comparison, Fig $3 \mathrm{~b}$ and $3 \mathrm{c}$ give SEM images of the composites. From which it can be clearly observed that the aluminum particles are tightly coated by carbon layer. With the increase of carbon content, the layer becomes thick and coarse.
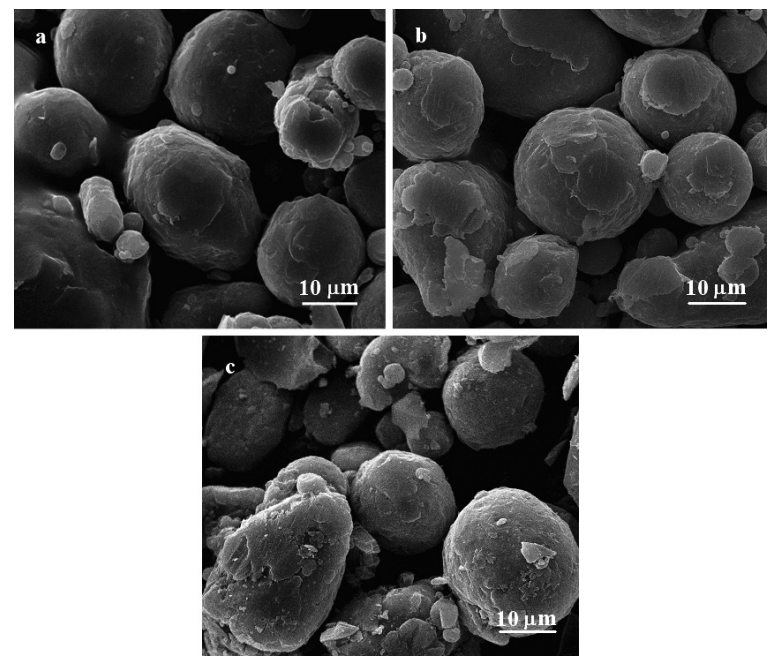

Figure 3. SEM images of pure aluminum and $\mathrm{Al} /$ carbon composites: (a) pure aluminum, (b) composite $\mathrm{A}$, and (c) composite $\mathrm{B}$.

\section{Electrochemical performance of Al/carbon composites}

Figure 4 displays the discharge and charge curves of pure aluminum and composites. In the case of pure aluminum, the first discharge curve mainly consists in three regions: ${ }^{1,11}$ the initial lithium insertion occurred between original potential and $0.2 \mathrm{~V}$, the following wide plateau at $0.2 \mathrm{~V}$, which is due to the formation of LiAl alloy, and the rest of $\mathrm{Li}$ insertion from 0.2 to $0.001 \mathrm{~V}$. In the first region, a short voltage plateau at around $0.7 \mathrm{~V}$ is clearly observed, which is due to the SEI formation of acetylene black for its characteristic coincides with that of pure acetylene black. The presence of this plateau in the first discharge curves of both composites and its absence from the second discharge curves can also manifest this. The first coulombic efficiency of pure aluminum is $76 \%$, the capacity loss is mainly derived from two aspects: (i) the SEI formation at the acetylene black interface and (ii) the LiAl alloying and the subsequent de-alloying processes. The $\mathrm{LiAl}$ alloying plateau at about $0.2 \mathrm{~V}$ possesses capacity of $586 \mathrm{mAh} \mathrm{g}^{-1}$, while the corresponding de-alloying plateau at around $0.4 \mathrm{~V}$ possesses capacity of $466 \mathrm{mAh} \mathrm{g}^{-1}$, indicating that part of LiAl can not de-alloy successfully. The dramatically reduction of alloying and de-alloying plateaus in the consecutive cycles indicates that the pure aluminum electrode has a fast capacity fading.

Compared with pure aluminum, two obvious features are observed in the first discharge and charge curves of composites: $(i)$ in discharge curves, the capacities of the 
first region enhance obviously with the increase of carbon content. The first region capacities of pure aluminum, composite $\mathrm{A}$ and $\mathrm{B}$ are 156, 238 and $278 \mathrm{mAh} \mathrm{g}^{-1}$ respectively, which should attributed to the participation of active carbon layer, (ii) in charge curves, the charge capacities reduce significantly with the increase of carbon content. The initial charge capacities of pure aluminum, composite A and B are 779, 734 and $444 \mathrm{mAh} \mathrm{g}^{-1}$ respectively, the irreversible capacities increase from 250 to $381 \mathrm{mAh} \mathrm{g}^{-1}$, and then to $528 \mathrm{mAh} \mathrm{g}^{-1}$. This phenomenon could be explained as follows. From XRD patterns we can conclude that the carbon layer is amorphous phase. It is known that the disordered carbons show large irreversible capacities in the first cycle, which is mainly due to three origins: ( $i$ ) the SEI formation on the carbon surface, (ii) the presence of suface functional groups and heteroatoms left from the organic precursor, which can react irreversibly with lithium and (iii) lithium ions trapping in the internal cavities. ${ }^{12}$ In addition, the trapped lithium ions in the carbon layer block the transfer of lithium from aluminum particles to other electric materials at a certain degree, thereby part of lithium ions are trapped in Al matrix. This affection is more obvious when the carbon content increases. From the charge curve of composite B, it can be clearly observed that the de-alloying plateau of LiAl alloy at around $0.4 \mathrm{~V}$ shortens distinctly. As a result, the irreversible capacities enhance with the increase of carbon content. Despite large irreversible capacities in the first cycle, the capacity fading of the composite electrodes is retarded effectively.

Figure 5a compares the cycle performance of pure aluminum and composites. The pure aluminum electrode shows a poor cycle life and holds only $21 \%$ of the initial reversible capacity after 15 cycles. By contrast, composite A and B exhibit improved cycle performance, whose capacity retentions are $38 \%$ and $58 \%$ respectively after 15 cycles, which are much higher than that of pure aluminum. The coulombic efficiencies of pure aluminum and composites are shown in Figure 5b. After the third cycle, the composites possess higher coulombic efficiencies than pure aluminum, especially for composite B, its efficiency reaches around $96 \%$ in the consecutive cycles. The improved cycle performance should attribute to the existence of carbon layer. Figure 6a gives the SEM image of pure aluminum after 1 cycle, where it can be seen that the pure aluminum electrode suffers severe volume expansion and the aluminum spherules are pulverized completely. The pulverization of aluminum results in the breakdown of conductive network between Al matrix and other electric materials especially the acetylene black, thereby the inserted lithium ions in $\mathrm{Al}$ matrix can not be extracted
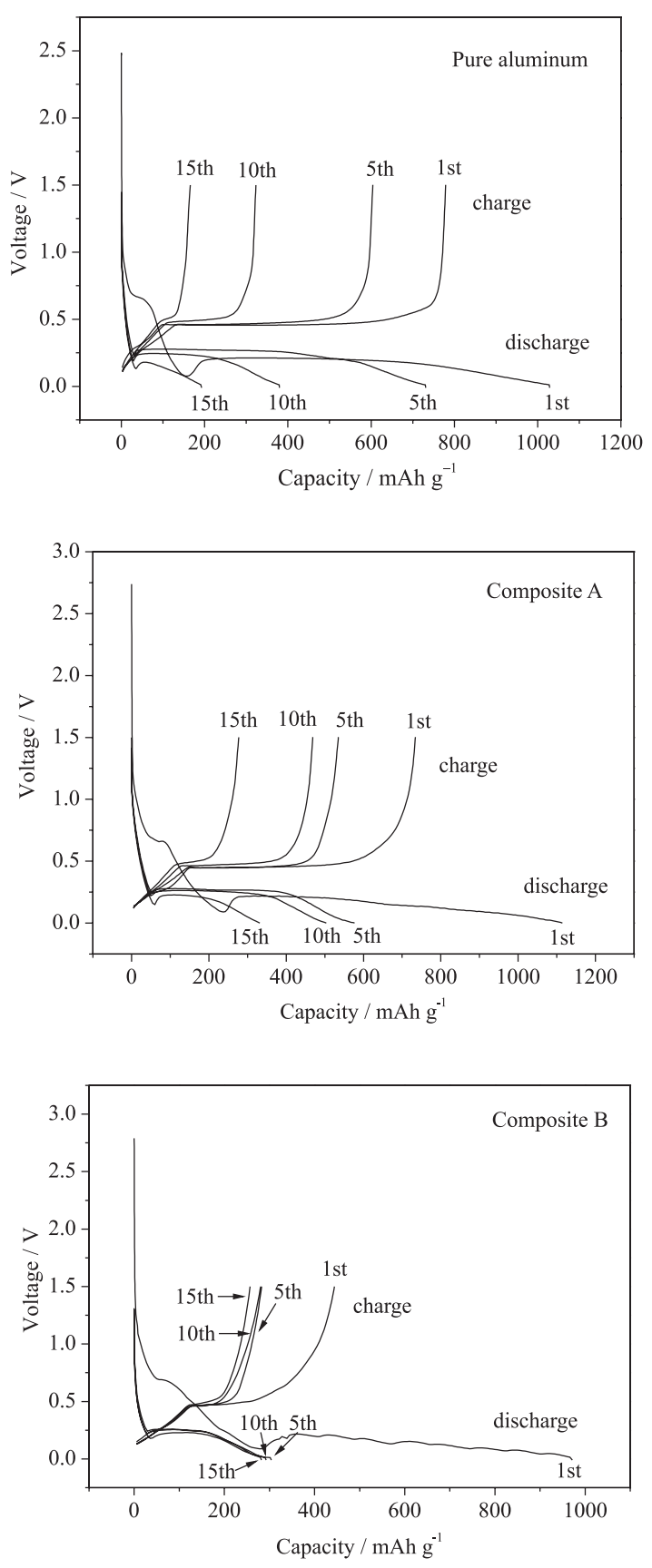

Figure 4. Charge/discharge profiles of pure aluminum and Al/carbon composites cycled between 0.001 and $1.5 \mathrm{~V}$ at a current density of $100 \mathrm{mAh} \mathrm{g}^{-1}$.

completely, most of them are trapped in the matrix, which leads to fast capacity fading. ${ }^{5}$ By contrast, in composite B electrode, the pulverization phenomenon is not observed after 1 cycle (Figure 6b), even after 10 cycles the aluminum particles still maintain basic spherical morphology (Figure 6c), which indicates that the carbon layer could play important roles in reinforcing the mechanical stabilities of aluminum particles and buffering the volume expansion of the metal matrix. 

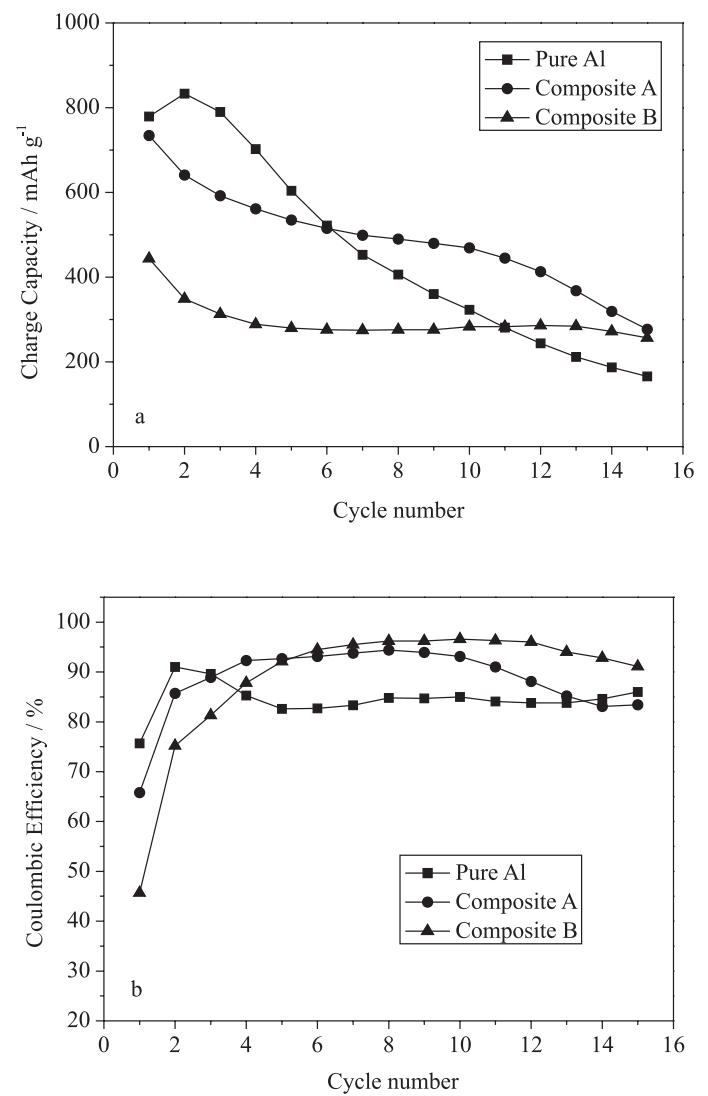

Figure 5. The cycleability and coulombic efficiencies of pure aluminum and $\mathrm{Al} /$ carbon composites cycled between 0.001 and $1.5 \mathrm{~V}$ at a current density of $100 \mathrm{mAh} \mathrm{g}^{-1}$.

\section{Conclusions}

$\mathrm{Al} /$ carbon composites were synthesized using polyvinyl alcohol (PVA) as carbon source. Results show that the carbon content affects the electrochemical performance of composites significantlly. Compared with pure aluminum, the composites present improved cycle performance, though the initial irreversible capacities increase. The existence of carbon layer could buffer the volume expansion of aluminum, thereby maintaining a stable conductive network between metal particles and other electric materials. Results indicate that carbon coating is a feasible method to improve the electrochemical performance of metal aluminum. The choice of carbon source and the synthesized method should be paid much attention in the subsequent research.

\section{Acknowledgements}

This work was supported by Guangdong Natural Science Foundation (No. 8452840301001692), Scientific Research Starting Foundation of University of Electronic

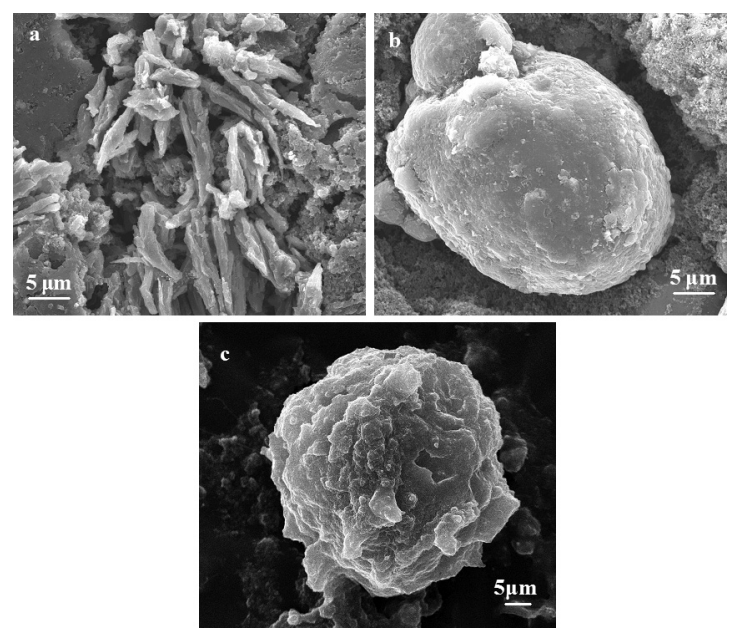

Figure 6. SEM images of pure aluminum and composite B after cycles: (a) pure aluminum after 1 cycle, (b) composite B after 1 cycle and (c) composite B after 10 cycles.

Science and Technology of China Zhongshan Institute (No. 2007YKQ16) and Youth Foundation of University of Electronic Science and Technology of China Zhongshan Institute (No. 407YJ01).

\section{References}

1. Hamon, Y.; Brousse, T.; Jousse, F.; Topart, P.; Buvat, P.; Schleich, D. M.; J. Power Sources 2001, 97, 185.

2. Winter, M.; Besenhard, J. O.; Electrochim. Acta 1999, 45, 31.

3. Larcher, D.; Beaulieu, L. Y.; Mao, O.; George, A. E.; Dahn, J. R.; J. Electrochem. Soc. 2000, 147, 1703.

4. Lindsay, M. J.; Wang, G. X.; Liu, H. K.; J. Power Sources 2003, 119,84

5. Jeong, G. -J.; Kim, Y. U.; Sohn, H. -J.; Kang,T.; J. Power Sources 2001, 101, 201.

6. Machill, S.; Rahner, D.; J. Power Sources 1997, 68, 506.

7. Zheng, T.; Xue, J. S.; Dahn, J. R.; Chem. Mater. 1996, 8, 389.

8. Dahn, J. R.; Zheng, T.; Liu, Y.; Xue, J. S.; Science 1994, 264 , 556.

9. McNeill, I. C.; J. Anal. Appl. Pyrolysis 1997, 40, 21.

10. Xiao, S. D.; Robert, Y. M.; Feng, X. S.; J. Membr. Sci. 2006, 286, 245.

11. Lei, X. F.; Wang, C. W.; Yi, Z. H.; Liang, Y. G.; Sun, J. T.; J. Alloys Compd. 2007, 429, 311.

12. Guerin, K.; Bouvier, A. F.; Flandrois, S.; Simon, B.; Biensan, P.; Electrochim. Acta 2000, 45, 1607.

Received: March 09, 2009 Web Release Date: November 6, 2009 